\title{
OSNOVI RAZUMJEVANJA BALANSIRANJA INTERESA I ŠTETA U ISLAMSKOM PRAVU (FIKHUL-MUVAZENAT)
}

\section{Sažetak}

Ova studija će pokušati pojasniti metode balansiranja izmecu interesa i šteta $u$ islamskom pravu. Pod pravnim balansiranjem se podrazumjeva nauka koja ima za cilj otkriti i pojasniti metode $i$ načine putem kojih se na najbolji $i$ naučan način realizuje poređenje izmedu samih interesa $i$ samih steta, ili izmedu interesa $i$ šteta kada dođu u koliziju i pokušati navedeno teoretisanje primjerima pretočiti u realnost. Najvažniji principi ili pravila na kojima počiva fikhul-muivazenat tj. pravno balansiranje su:

1- balansiranje izmedu samih interesa $u$ smislu njihova preferiranja $i$ zanemarivanja,

2- balansiranje izmedu samih šteta u smislu njihovog obaveznog uvažavanja kad ih je nemoguce izbjeci, te njihova zanemarivanja ili odgadanja,

3- balansiranje izmedu interesa i steta u smislu definiranja pravila na osnovu kojih je obavezno preferirati štetu nad koristi ili zanemariti steta na uštrb koristi.

Po pitanja pravnih balansiranja interesa $i$ steta islam slijedi princip uskladivanja i pomirenja mecu interesima kad god je to moguce, a ukoliko nije, onda pribjegava prevladavanju i preferiranju. Predmet proučavanja ove vrste islamskog prava su šerijatski propisi $i$ norme, tj. djela pravnih adresata koja involviraju ovosvjetske $i$ onosvjetske interese jer se na ta djela i interese upravo $i$ odnose šerijatske norme. Šerijatski propisi $i$ norme su propisane upravo radi realizacije ljudskih interesa $i$ uklanjanja šteta kako to $i$ navodi imam Sujuti tvrdeći da sve Božije naredbe i zabrane u krajnjem ishodu imaju $z a$ cilj da uvaže interese, a $i$ samo uklanjanje šteta je u osnovi jedna vrsta interesa.

Ključne riječi: pravno balansiranje, uskladivanje, prevladavanje, interesi, stete, fikh, islamsko pravo.

${ }^{1}$ Islamski pedagoški fakultet u Bihaću. 


\section{UVOD}

Po većini islamskih pravnika islamske norme i propisi su razložni, te su stoga i propisani kao sredstva za realizaciju svojih ciljeva ili intencija, te nisu svrha sami sebe. Dakle, propisani su radi sveopćih ovosvjetskih i onosvjetskih interesa ljudi ${ }^{2}$. Ponekad ti interesi mogu doći u koliziju u smislu da ih je nemoguće sve realizovati i uvažiti. Također i štete mogu doći u kontradiktornost kada ih je nemoguće sve izbjeći. Zatim same štete i koristi mogu doći u koliziju kao npr. da ista stvar u isto vrijeme u sebi involvira i korisno i štetno, ili je za nekoga korisna a nekoga štetna. U tom slučaju islamsko pravo za razumijevanje takvih pravnih slučajeva primjenjuje nekoliko metoda pravnog balansiranja koje će i biti tema ove studije.

\section{Fikh balansiranja - historijski presjek}

Islamski pravnici su se uveliko zanimali za ovu vrstu prava. Prvi ko se, po našem mišljenju, počeo zanimati za ovu vrstu prava je imam Gazali u svom enciklopedijskom djelu Ihjau 'ulumid-dinu. U Poglavlju o osudi samodopadljivosti naveo je vrste pobožnjaka i njihovih djela koja ih dovode do propasti a da to i ne osjećaju. On u tom poglavlju navodi da su to oni koji su zanemarili farzove na račun nafila pa se raduju klanjanju duha ili noćnog namaza, dok u farzovima ne osjećaju nikakvu slast, a niti se trude da namaz klanjaju u njegovom prvom vremenu. Isto tako on osuđuje i bogataše koji nastoje svim silama da svake godine obave hadždž a možda su kod kuće ostavili komšije gladne i nezbrinute. Naveo je još mnogo primjera koji zorno govore o njegovom dubokom i pravilnom razumijevanju vjere. I na kraju tog poglavlja zaključuje da je svako onaj ko zanemari redoslijed prioriteta u biti obmanjen. Potom konstatuje da je takva vrsta obmane najopasnija, jer se radi o pokornosti gdje čovjek ne primjećuje da se takva vrsta pokornost transformiše u

\footnotetext{
${ }^{2}$ Ovdje treba istaći da se pod interesima i štetama misli samo i isključivo na one interese koje je Zakonodavac namjeravao realizovati svojim naredbama, te na štete koje je mislio ignorisati svojim zabranama. Prema tome, kada govorima u ovoj studiji o interesima i štetama nikako ne mislimo na štete i interese koje se ljudima doimaju i koje traže njihovi nagoni, prohtjevi i strasti.
} 
grijeh jer se namjerno i svjesno zanemaruje obligatna dužnost na račun poželjne ili preporučene. ${ }^{3}$

Nakon Gazalija, dolazi imam Ebul-Ferdž b. El-Dževzi. U njegovim djelima poput Telbisul-iblis, Sajdul-hatir, Zemmul-heva i drugima se jasno vidi da je on ovu disciplinu islamskog prava izvrsno poznavao $\mathrm{i}$ uveliko je primjenjivao u svojim pravnim decizijama i promišljanjima.

Potom dolazi Izuddin b. Abdusselam, koji se smatra jednim od najvećih učenjaka u ovoj oblasti islamskog prava. On je u svom kapitalnom djelu Kava'idul-ahkami fi mesalihil-enam otkrio i definirao cijelu teoriju pravnog balansiranja, tj. prava balansiranja. Isto tako, veliki doprinos ovoj nauci je dao i Ibn Tejmijje u svojim poznatim djelima kao i njegov učenik Ibnul-Kajjim El-Dževzijje.

Savremeni islamski pravnici su se također bavili ovom vrstom prava posebno onda kada bi istraživali neka pitanja i teme iz fikha prioriteta poput dr. Jusufa Karadavija o čemu je govorio u nekim svojim djelima i naveo da fikh prioriteta ima veze sa fikhom balansiranja i da su oni ponekad $\mathrm{u}$ korelacijskoj vezi i usko povezani $\mathrm{u}$ smislu da fikh balansiranja ponekad dopre do određenih granica fikha prioriteta $\mathrm{i} \mathrm{u}$ tom slučaju se pomiješa sa njim. ${ }^{4}$

\section{Metodologija fikha balansiranja}

Metodologija ove vrste prava se može sažeti u četiri pravila, jer onaj koji se bavi ovom naukom, kod kontradiktornosti samih interesa ili samih šteta ili oprečnosti interesa i šteta, treba početi od primjene pravila njihova pomirenja - et-tevfik i usklađivanja - el-džem'. Znači, kada se mognu uvažiti i realizovati svi interesi to se mora učiniti i nikako se ne smiju zanemariti. Ukoliko ne mognu, onda će se primjeniti metod prevladavanja - et-taglib i preferiranja - et-terdžih. U tom slučaju će se uvažavati korisniji i bolji interesi nad dobrim i manje korisnim. Te će se preferirati uklanjanje štete nad pribavljanjem koristi kada budu identične. Ukoliko se interesi izjednače i ne mogne se prevladati ili preferirati jedan nad drugim u tom slučaju će se primjeniti

\footnotetext{
${ }^{3}$ Gazali, Ihjau 'ulumid-din, Darul-m'arife, Bejrut, 2/400.

${ }^{4}$ Vidi: Karadavi, Evlevijatul-hareketil-islamijjeti fil-merhaletil-kadimeh, Muessesetur-risale, Bejrut, 13. izdanje., 1992., str. 39.
} 
metod pravne selekcija, a kada se izjednače prava onda se može pristupiti metodu izvlačenja i strelica.

Navedena četiri pravila ili metode mogu se elaborirati sljedećim redoslijedom:

Prvo pravilo - Usklađivanje i pomirenje interesa,

Drugo pravilo - Prevladavanje i preferiranje interesa kad je nemoguće primjeniti prvo pravilo,

Treće pravilo - Selekcija interesa u situaciji kada se izjednače i ne bude moguće primjeniti drugo pravilo $\mathrm{i}$

Četvrto pravilo - Izvlačenje strelica kada se prava izjednače zbog uklanjanja prikrivene mržnje i pakosti.

\section{Prvo pravilo - Usklađivanje et-tevfik i pomirenje el-džem'}

Imam Izuddin b. Abdussselam je naveo mnoge primjere primjene ovog pravila od kojih su:

- Ukoliko bi neko dok klanja namaz vidio utopljenika kako se guši dužan bi bio prekinuti namaz i spasiti ga a potom naklanjati namaz. Ovaj primjer zorno govori o pomirenju interesa, a imam Izuddin ga obrazlaže na taj način što konstatuje da je spašavanje nevinih života kod Allaha važnije od obavljanja namaza. Pomirenje dva interesa u ovom slučaju moguće je tako što će se prvo spasiti davljenik a potom klanjati namaz. Općepoznato je da se ono što se propustilo od namaza ni približno ne može mjeriti sa spašavanjem muslimana od smrti. Imam je ovo pitanje promatrao i generalno oslanjajući se pri tome na ono što nalažu šerijatske intencije - načela i principi koji aludiraju na to da je šerijat uspostavljen na temelju pribavljanja koristi i uklanjanju štete od ljudi i da je korist očitija i potvrđenija u prekidanju namaza i spašavanju davljenika, a šteta u neprekidanju namaza i zanemarivanje utopljenika. Šteta koja proističe od neprekidanja namaza i zanemarivanje utopljenika je veća od štete prekidanja namaza i isteka njegovog propisanog vremena. To je generalni pogled i mjerenje stvari sa metodom prevladavanja i preferiranje interesa i šteta. Upravo je to ono što je naložio taj propis kojeg je pojasnio imam Izuddin, tj. vizija koja se oslanja na šerijatske intencije što je očito i jasno. Ista je stvar i sa postačem kada u ramazanu vidi nekoga ko se utapa a ne može ga spasiti 
bez prekidanja posta. U tom slučaju će prekinuti post i spasiti utopljenika. I ovaj primjer također odražava primjenu pravila pomirenja među interesima, jer u životima ljudi ima i Allahovo pravo kao i pravo ubijenog. Stoga se taj interes preferiran nad interesom posta.

- Okretanja u namazu suprotno od kible je zabranjena šteta. Međutim, u stanju straha, kada se ratnik ne može okrenuti prema njoj, taj uvjet se anulira pa će strana prema kojoj se može okrenuti postati njegova kibla. I ovdje se radi o principu pomirenja dva interesa; interesa džihada $\mathrm{i}$ interesa namaza.

- Kada čovjek bude prisiljen da konzumira tuđi imetak u situaciji kada se boji za svoj život ili zdravlje, u tom slučaju mu to postoje dozvoljeno uz obaveznu kompenzaciju tuđe imovine, jer je zabrana tuđe imovine na manjem stepenu od zabrane uništenja života. Uništenje života je veća šteta od uništenja tuđe imovine. Prema tome, realizacija jednog interesa uz kompenzaciju drugog je preče od uvažavanje jednog interesa $\mathrm{i}$ uništenja alternative drugog.

Navedeni primjeri odražavaju partikularni idžtihad u kojem su se uzeli u obzir generalni dokazi pri primjeni partikularnih. Imam Šatibi smatra da je neophodno pri proučavanju posebnih partikularnih dokaza uzeti u obzir tri univerzalne vrste interesa: nužne, potrebne i poželjne interese. Prema tome, partikularne dokaze je neophodno promatrati kroz prizmu generalnih koji su u odnosu na njih arbitrarni i koji definiraju njihova značenja i poimanja, jer nije dozvoljeno odvojiti partikularni dokaz od generalnog, zbog toga što su partikularni dokazi podložni generalnim. Isto tako nije dozvoljeno ni uvažiti generalne a zanemariti partikularne. Ukoliko bi se islamski pravnik ograničio samo na partikularne dokaze ne pridavajući pri tome bilo kakvu važnost generalnim, koji su osnova partikularnim, bez sumnje će u tom slučaju izvesti propise i decizije koje će biti oprečne mudrostima i duhu šerijata. ${ }^{5}$

\section{Drugo pravilo: Prevladavanje et-taglib i preferiranje et-terdžih u slučaju kontradiktornosti interesa ili šteta}

Drugo pravilo u fikhu balansiranja nalaže da ukoliko se ne mogne primjeniti prvo da se onda pristupi preferiranju onih interesa koji su

${ }^{5}$ Vidi: Šatibi, El-Muvafekat, 3/5-8. 
bolji i najbolji, te korisniji i najkorisniji. Ovo pravilo ima svoje utemeljenje i u Kur'anu: Zato obraduj robove Moje koji Kur'an slušaju i slijede ono najljepše u njemu; njima je Allah na Pravi put ukazao i oni su pametni. (Ez-Zumer, 17,18, 55.)

Isto tako, ovo pravilo nalaže i da uvažimo manju štetu kako bismo izbjegli veću u slučaju kada se nađu interesi i štete po jednom te istom pitanju ili kada je jednu od njih obevezno prihvatiti zbog određenih razloga. Ustvari, ovo je to mjerilo kojeg je islam postavio pri zaštiti interesa $\mathrm{i}$ njihovih posljedica kao i njihova pravilna razumijevanja $\mathrm{i}$ stepenovanja po važnosti. Njega se svaki mudžtehid pri svom idžtihadu treba pridržavati na segmentu interesa i šteta kada su predmet njegova istraživanja pitanja o kojima nema pravnih tekstova. ${ }^{6} \mathrm{Na}$ osnovu navedenog nastalo je generalno pravilo $u$ islamskom pravu da se kod kontradiktornosti interesa uvažavaju najvažniji na račun manje važnih. Međutim, ukoliko dođe do kontradiktornosti šteta, u tom slučaju se čini manja na uštrb veće. Ovo pravilo se može potvrditi kur'anskim kazivanjem o Hidru kada se zajedno ukrcao sa Musaom, a.s., na lađu pa ju je potom probušio. U tome je bila očita šteta, ali i pored toga Hidr ju je počinio kako bi spriječio veću, a to je uzurpacija cijele lađe od strane nepravedna vladara da je ostala ispravna. Stoga ćemo se u nastavku studije ukratko osvrnuti na pravilo preferiranja kontradiktornosti interesa, zatim šteta, te pravilo preferiranja interesa i šteta.

\section{Pravilo preferiranja kontradiktornosti interesa}

Primjenu ovog pravila određuje nekoliko potpravila od kojih su:

\section{1 - Veći interesi se preferiraju nad manjim}

Općepoznato je da su svi šerijatski propisi propisani isključivo radi zaštite i očuvanja pet univerzalnih ljudskih vrijednosti koje su islamski pravnici zapazili, otkrili i poredali po važnosti i obimu interesa. To su: vjera, život, razum, potomstvo i imovina. Potom su sredstva za očuvanje svake od tih vrijednosti stepenovana također sukladno važnosti samih vrijednosti: nužne, potrebne i poželjne. Prema tome,

\footnotetext{
${ }^{6}$ Buti, Davabitul-maslehati fiš-šeri'atil-islamijjeh, Muessesetur-risale, Bejrut, četvrto izdanje, 1983., str. 248.
} 
norme i propisi koji su propisani radi zaštite i očuvanja nužnih vrijednosti se kod kontradiktornosti preferiraju nad istim koje su propisane za zaštitu i očuvanja potrebnih. One koje su propisane za zaštitu i očuvanje potrebnih se preferiraju nad istim koje su propisane za zaštitu poželjnih. Dakle, zanemaruje se potrebni interes, koji nije nužan, radi očuvanje esencijalnog, kao što se isto tako zanemaruje i poželjni, za kojim nema potrebe, radi očuvanja potrebnog. A svi navedeni interesi kod oprečnosti se preferiraju nad dopunjujućim ili upotpunjavajućim et - tekmili.

$\mathrm{Na}$ osnovu tih preferiranja i balansiranja koristi i šteta islamski pravnici su odobrili džihad sa nepravednim vladarima sukladno hadisu u kojem je Poslanik, a.s., rekao: „Džihad je vadžib sa svakim vladarom pravednim i nepravednim, namaz vama je isto tako vadžib za svakim muslimanom bio moralan ili nemoralan pa makar radio i velike grijehe. ${ }^{67}$ Dakle, ovdje je zanemaren sunet naspram nužde zaštite vjere putem džihada. Isto tako je preferirana uspostava džemata u džamiji a zanemareni su poželjni uvjeti. Postavljanje pravednog vladara i njegovo slijeđenje su potrebne i obavezne stvari za muslimane. Međutim, Poslanik, a.s., je naredio da se ta obaveza zanemari ako sprečava izvršenje nužde, u ovom slučaju džihada. Stoga je propisao obaveznost džihada pa čak i sa nepravednim vladarom. Isto tako, izbor najboljeg imama po znanju i moralu za namaz je od poželjnih interesa koje je islam propisao, ali je to Poslanik, a.s., zanemario ako će njegova primjena doći u koliziju sa onim što je potrebno poput obavljanja namaza u džematu ukoliko u nekom mjestu ne bude bilo moralnih i učenih imama. ${ }^{8}$ U tom smislu Šatibi je rekao: „Džihad je nužda kao što je i vladar nužda, a njegova moralnost je na stepenu upotpunjavajućih interesa nužnim interesima. A upotpunjavajući interes ukoliko bude implicirao anuliranje nužnog ne smije se uvažiti. Stoga je od Poslanika, a.s., došla naredba da se džihad vodi i sa nepravednim vladarima, kao i da se klanja iza nemoralnih imama, jer je u suprotnom napuštanje sunneta džemata, a džemat je vjerski obred koji se traži, a moralnost

\footnotetext{
${ }^{7}$ Ebu Davud, Sunen, Darul- fikr, 3/18., Bejheki, Es-Sunenul-kubra, Mektebetud-darilBaz, Mekke, 1994., 3/121., 8/185. Neki ga ocjenjuju negativno tj. da je slab. Međutim, po njemu postupa Ummet i prenosi se na više načina. Vidi: Zejle'i, Nasbur-rajeti li ehadisil-Hidaje, Darul-hadis, 2357. H., 2/26.
}

${ }^{8}$ Buti, Davabitul-maslehati fiš-šeri'atil-islamijjeh, str. 257. 
kod imama upotpunjava to traženo pa se stoga ne smije poništiti primarno radi sekundarnog. “9

Ukoliko se radi o dva kontradiktorna interese koji su na istom stepenu i svaki od njih se posebno odnosi na jednu od pet univerzalnih vrijednosti, oni će se preferirati sukladno preferiranosti interesa na koje se odnose. Tako će se nužni interes, koji se odnosi na vjeru, preferirati nad nužnim interesom koji se odnosi na život. Onaj koji se odnosi na razum će se preferirati nad onim koji se odnosi na potomstvo, a onaj koji se odnosi na razum nad onim koji se odnosi na imovinu. Tako je npr. džihad vadžib bez obzira na sve gubitke života i drugih vrijednosti u njemu, jer se zaštita vjere preferira nad zaštitom života. Stoga se alkohol dozvoljava u nuždi zbog toga što je zaštita života preča od zaštite razuma, itd.

\section{2 - Preferiranja opće koristi nad posebnom}

Kada se nađu dva oprečna interesa koji se odnose na jednu od pet univerzalnih vrijednosti i ne mogne se među njima naći kompromis, prednost će se tada dati općem interesu radi postizanja što veće koristi. Dakle, preferirat će se općenitiji i obuhvatniji interes nad onim koji to nije. Isto tako prilikom procesa idžtihada se treba preferirat općenitiji i sveobuhvatniji nad specifičnijim interesom pod uvjetom da se zaštiti individualno pravo putem kompenzacije ukoliko je to moguće, jer nelogično je da se zanemari korist kojom se realizuje interes svih ljudi poradi zaštite koristi od koje ima interes samo jedan čovjek ili neka mala grupica. Ovdje treba istaći da se preferiranjem općeg interesa niukom slučaju ne nanosi šteta individualnom, zbog toga što je i pojedinac dio društva i zajednice. Stoga se putem zaštite društva štiti i sam pojedinac i obratno. Ali, ukoliko bismo štitili samo pojedinca nanoseći pri tome štetu zajednici, na taj način bi pojedincu bila nanesena dupla šteta.

Za ovu vrstu preferiranja mogu se navesti sljedeći primjeri:

- Poslanik, a.s., je zabranio da građanin prodaje seljakovu robu, kao što je zabranio i presretanje trgovačkih karavana pred gradom radi zaštite opće koristi koja se ogleda u interesu svih građana i ostalih trgovaca

${ }^{9}$ Šatibi, Muvafekat, 2/330. 
koji prodaju na pijacama tog grada a individualna samo presretača koji će preuzetu robu prodavati po većim cijenama.

- Zabrana monopola i prisilno preuzimanje robe iz njegova vlasništva po uobičajenoj cijeni. U tome se ogleda preferiranje općeg interesa nad individualnim, tj. interesa svih ljudi gdje im se obezbjeđuju osnovne životne potrebe po uobičajenim cijenama nad interesom monopoliste.

- Preferiranje interesa zaštite razuma od zabluda, obmana i manipulacija nad interesom ili pravom slobode na govor i mišljenje u slučaju kada dođu u koliziju. Stoga što je prvi interes opširniji i općenitiji od drugog, tj. što je šteta koja proističe od zanemarivanja prvog interesa opasnija od štete koja bi nastala od zanemarivanja drugog. Treba još istaći da su oba interesa na stepenu potrebnih. Dakle, iz navedenih i njima sličnih primjera se jasno primjećuje da se opći interes preferira nad individulanim i da je to upravo i namjera Zakonodavca. Svakako o tome ne postoji poseban dokaz, ali se to zaključuje iz navedenih i njima sličnih pravnih tekstova i primjera.

\section{3 - Preferiranja stalnog nad relativnim i nekonstantnim interesom}

Ukoliko dođe u koliziju interes koji je relativan i nestalan sa onim koji je stalan i konstantan, zanemarit će se prva vrsta interesa. Kao primjer može se navesti postupak Omera, r.a., kada je odlučio da iračke plodne ravnice nakon njihova osvajanja uvakufi za opće dobro svih muslimana odustajući od do data uobičajene prakse da se i nekretnine dijele među mudžahidima. ${ }^{10}$ Primjetio je da bi podjela te zemlje bila nepravedna $\mathrm{u}$ odnosu na buduće generacije. Stoga je rekao svoju poznatu izreku: „Da nema potonjih generacija muslimana, podijelio bih mudžahidima svako selo kako je to činio i Poslanik, a.s., sa Hajberom." ${ }^{11}$ Dakle, Omer je potpuno shvatio i razumio Kur'an, sunnet i ciljeve šerijata i takvo shvatanje primijenio u praksi preferirajući interese svih generacija muslimana nad interesima jedne ili dvije generacije. Stoga se prema generacijama koje još nisu došle odnosio kao i prema postojećoj.

\footnotetext{
${ }^{10}$ Poslanik, a.s., je uveo tu praksu i dijelio bi osvojenu zemlju mudžahidima nakon što bi odvojio petinu za islamsku državu. Tako je uradio i nakon osvojenja Hajbera.

${ }^{11}$ Buhari, El-Džami'us-sahih, Dar Ibn Kesir i Jemame, Bejrut, 1987., 2/822.
} 


\section{4 - Preferiranje primarnog i osnovnog interesa nad formalnim}

Kao primjer za ovo pravilo se može navesti ugovor na Hudejbiji o primirju koji je potpisano između Poslanika, a.s., i mekkanskih idolopoklonika na period od deset godina. U tom ugovoru se jasno vidi da Poslanik, a.s., preferira esencijalne, glavne i buduće interese nad formalnim i banalnim koje neki muslimani u to vrijeme nisu mogli razumjeti i prihvatiti. Poslanik, a.s., je u tom ugovoru prihvatio neke uvjete koji se na prvi pogled čine nepravednim i ponižavajućim za muslimane. Pored ostalih bili su i sljedeći: ${ }^{12}$

- da se izbriše bismilla sa dokumenta ugovora,

- da se izbriše atribut Božiji poslanik napisan pored Poslanikova imena, - da se te godine muslimani vrate u Medinu bez obavljene umre koju će obaviti tek iduće godine $\mathrm{i}$

- da se svako onaj ko dođe iz Mekke kao musliman Poslaniku, a.s., mora vratiti idolopoklonicima, dok u obratnom slučaju to pravilo ne vrijedi. Ashabi su tada rekli: „Allahov Poslaniče, zar ćemo i to prihvatiti?!“ Rekao je: „Da, jer onaj koji ode od nas njima nek ga Allah udalji a onaj koji dođe nama Allah će mu dati izlaza.“"13

U navedenom ugovoru Poslanik, a.s., je dao idolopoklonicima sve uvjete koje su tražili. Dakle, bio je tolerantan s njima u pitanjima u kojima niko od ashaba u to vrijeme nije mogao naći opravdanja da se tolerišu i prihvate. Stoga je Omer, r.a., bio krajnje uznemiren i zabrinut, a među ashabima je zavladalo negodovanje kad im je Poslanik, a.s., naredio da se obriju i zakolju kurbane, tj. oslobode ihrama umre koju su naumili obaviti te godine. ${ }^{14}$

Uistinu su se bendovi Ugovora na Hudejbiji doimali na prvi pogled kao da je taj ugovor u potpunosti bio u korist idolopoklonika a na štetu muslimana, te da im njegova primjene niukom slučaju neće donijeti nikakvu korist. Međutim, u biti i po svojim posljedicama taj ugovor je bio u korist muslimana jer se pokazao kao velika pobjeda islama $\mathrm{i}$

\footnotetext{
12 Vidi, Ibn Hišam, Es-Siretun-nebevijjeh, Darur-rejjan, Kairo, prvo izdanje, 1987.god., 3/355.

${ }^{13}$ Muslim, Džami'us-sahih, hadis br. 1784.

${ }^{14}$ Vidi: Buti, Fikhus-sire, Darul-fikr, Damask, 1996., 11. izdanje, str. 23.
} 
muslimana pa ga je i sam Kur'an nazvao jasnom pobjedom - fethan mubina.

\section{5 - Preferiranje sigurnog interesa nad umišljenim}

Obavezno je kod preferiranja jednog interesa nad drugim da korist od onoga koji se preferira ne bude umišljena i pored toga što je preferiranija sa strane same njegove važnosti.

Kao primjer se može navesti obaveznost džihada muslimana u stanju kada su malobrojniji ili slabije opremljeni, tj. kada prevladava mišljenje da će biti pobijeni a da u isto vrijeme neće moći nanijeti nikakve štete neprijatelju. Ovdje se preferira interes očuvanja života nad umišljenim interesom zaštite vjere, jer je u tom slučaju interes zaštite vjere umišljen ili je interes čija realizacija je odbačena. Izuddin b. Abdusselam tvrdi da je čak zabranjeno - haram u takvom slučaju voditi džihad. U tom smislu je rekao: „Ukoliko se ne nanese šteta neprijatelju, onda je nužan poraz, jer vođenje džihada zahtjeva uništenje života, tj. poraz kao i radost nevjernika a nesreću vjernika. Zbog toga je u ovakvoj situaciji vođenje rata čista šteta i u tome nema interesa. ${ }^{\text {(15 }}$ Dakle, neko djelo se klasificira na štetno ili korisno na osnovu posljedica koje proizvodi njegova primjena u stvarnosti. Stoga nije dozvoljeno preferiranje jednog interesa nad drugim ukoliko je umišljen ili nestvaran bez obzira kakva njegova vrijednost i sveobuhvatnost bila. Preferira se samo onaj interes koji je kategoričan ili skoro kategoričan, jer je Zakonodavac interesu koji ima status skoro kategoričnog u praktičnim propisima dao status kategoričkog ukoliko se takvo uvjerenje ne derogira jačim od njega. $^{16}$

\section{Kontradiktornost šteta i pravila njihova preferiranja}

Kao što interesi mogu doći u kontradiktornost isto tako mogu i štete, jer i one nisu identične nego se razlikuju po svom obimu, posljedicama i opasnostima. Npr. šteta koja ugrožava nužni interes nije ista kao ona koja ugrožava potrebni, a niti je ista ona koja poništava potrebni kao ona koja to čini poželjnom. Isto tako, šteta koja ugrožava imovinu nije

\footnotetext{
${ }^{15}$ Izuddin b. Abdusselam, Kava'idul-ahkam, 1/95.

${ }^{16}$ Buti, Davabitul-masleha, str. 254.
} 
ista kao ona koja ugrožava život, a njih obje opet nisu na stepenu onih koje ugrožavaju vjeru i iman. U tom smislu Izuddin b. Abdusselam je rekao: „Kada se nađu čiste štete pa ih je moguće uklonuti, ukloniće se. Ukoliko je nemoguće sve anulirati, ukloniće se jedna po jedna i to na osnovu njihova obima štete i zla. Ukoliko budu sve na istom stepenu, onda će se ponekad biti suzdržano a ponekad će se napravit selekcija. Stoga što njihove razlike mogu biti i kod identičnosti kao i kod različitosti. I pri tome, nema razlike između šteta koje imaju status harama ili mekruha." ${ }^{17}$

Islamski pravnici su na osnovu navedenog principa definirali nekoliko pravila koja regulišu najvažnije propise koji se tiču šteta, od kojih su:

- Šteta se ne uklanja sa istom ili većom od nje. Stoga onome koji je u nuždi nije dozvoljeno jesti hranu drugog koji je u istoj nuždi kao i on.

- Kada dvije štete dođu u koliziju u obzir će se uzeti veća a manje će se zanemariti, jer veća šteta se uklanja sa manjom, te se uvijek odabire manje zlo. Kao dokaz može se navesti Hidrovo opravdanje bušenja lađe koju je počinio s namjerom da lađu ostavi u vlasništvu siromaha, jer je njeno bušenje bilo manja šteta od gubljenja cijele lađe. Prema tome, i parcijalna zaštita i parcijalno očuvanje nečega je bolje i preče od integralnog gubljenja i integralne štete. Kurtubi je rekao: „Dozvoljeno je očuvati cijeli imetak sa uništenjem njegovog dijela. Kao što je i staratelju siročeta dozvoljeno dati dio njegova imetka da bi sačuvao ostatak." ${ }^{\prime 18}$

Od Enesa b. Malika se prenosi da je neki beduin mokrio u džamiji pa su neki od ashaba ustali da ga spriječe. Poslanik, a.s., je na to rekao: „Ostavite ga i ne prekidajte." Kada je završio naredio je da donesu posudu vode i prospu na to.“19 Imam Nevevi je rekao: „U hadisu je dokaz da se veća šteta uklanja sa podnošenjem manje. Poslanik, a.s., je rekao da ga ostave zbog dvije koristi. Prva: da su ga prekinuli nanio bi sebi štetu jer se u stvarnosti onečišćenje već desilo pa bi se sa njegovim prekidanjem ono povećalo. Druga: onečišćenje se desilo na vrlo malom

\footnotetext{
${ }^{17}$ Izuddin b. Abdusselam, Kavaidul-ahkam, 1/ 79.

18 Kurtubi, El-Džami'u li ahkamil-Kur'an, Darul-hadis, Kairo, prvo izdanje, 1994., $1 / 40$.

${ }^{19}$ Nevevi, Šerhu Muslim, Ihjaut-turasil-arebi, Bejrut, 3/190.
} 
prostoru džamije. Stoga da su ga prekinuli dok je urinirao uprljao bi svoju odjeću, tijelo i mnogo više džamijskog prostora. “20

- Podnosi se individualna šteta da bi se spriječila opća. Ovo pravilo je ograničeno sa drugim: Šteta se ne uklanja sa istom. Na osnovu ovih pravila učenjaci su izveli mnoge propise poput: Zabrane nestručnom ljekaru i muftiji, kao i trgovcu koji je bankrotirao, da upražnjavaju svoja zanimanja zbog štete koja se od prve zabrane reflektuje na tijelima, od druge na vjeri a od treće na imovini.

- Ako se nađu nečije kuće i zgrade pored puta u ruševnom stanju njihov vlasnik će se prisiliti da ih ukloni iz straha da se ne obruše na prolaznike.

- Dozvoljeno je odrediti cijene robama zbog mogućnosti dogovora trgovaca da osnovne životne potrebe prodaju po nerealnim cijenama.

- Dozvoljeno je ubiti sihirbaza koji nanosi štetu ljudima i na taj način im nanosi zlo. U ovom slučaju se podnosi posebna šteta da bi se uklonila opća.

\section{Pravila koja se primjenjuje kod oprečnosti interesa i šteta}

U slučaju kada se po istom pitanju nađu šteta i korist ili interes i gubitak, neophodno je tada izvršiti balansiranje među njima. U obzir će se uzeti ono što prevlada ili čega bude više, jer većini se daje status cjeline. Kada u kontradiktornost dođe korist i šteta i kada je neophodno konzumirati štetu ukoliko se uvaži interes, ili zanemariti koristi ukoliko se izbjegne šteta, u tom slučaju će se uzeti u obzir obim svake od njih i napravit će se balansiranje na sljedeći način:

a - Ukoliko šteta bude veća od koristi u tom slučaju se uklanja šteta a zanemaruje korist. Kao primjer može se navesti ajet u kojem se jasno kaže da je u alkoholu i kocki veći grijeh od njihove koristi. ${ }^{21}$

b - Ukoliko korist i šteta budu izjednačene, u tom slučaju se uklanjanju štete daje prednost nad pribavljanju koristi sukladno pravnom pravilu da se preferira uklanjanje štete nad pribavljanjem koristi. $\mathrm{Na}$ osnovu toga, dozvoljeno je zanemariti dio obligatne dužnosti, ili cijelu dužnost - vadžiba radi uklanjanja štete. Kao npr. dozvoljeno je ostaviti stajanje

\footnotetext{
${ }^{20}$ Ibid, 3/191.

${ }^{21}$ Kur'an, El-Bekare, 219.
} 
u namazu kao i post u ramazanu, ali se od zabrana ništa ne toleriše a posebno kada se radi o velikim grijesima. $\mathrm{Na}$ osnovu tog pravila, zabranjena je prodavati alkohol, drogu, itd., i pored toga što donose velike ekonomske koristi. Isto tako se zabranjuje svakom čovjeku da raspolaže svojom imovinom ukoliko će svom komšiji nanijeti štetu.

c - Ukoliko korist bude veća od štete u tom slučaju će se preferirati korist i pored toga što će uzrokovati neznatnu štetu. Zbog toga se ne zabranjuju stvari koje rijetko kada vode ka šteti i čija je korist veća od štete poput sadnje grožđa, šljiva, viđenje zaručnice, svjedoka, itd., jer Zakonodavac je donosio propise na osnovu pretežnog interesa a da pri tome nije uzimao u obzir štete koje su iznimne i rijetke i ovo pravilo je prihvaćeno od strane svih islamskih pravnika. Stoga Zakonodavac prihvata presudu na osnovu svjedoka i pored postojanja mogućnosti da pri svjedočenju ne izreknu istinu, kao što prihvata i svjedočenje žene o isteku njena iddeta i pored mogućnosti da ne bude iskrena., itd. Međutim, pošto te mogućnosti nisu vjerovatne Zakonodavac ih je zanemario i nije ih uvažio, jer se sigurni interesi ne smiju zanemariti zbog rijetke i vjerovatne štete. A ukoliko bi se prihvatilo da se na osnovu umišljenih i nerealnih interesa donose norme i propisi, onda bi to impliciralo potpunim poništenjem halala, jer na ovom svijetu ne postoji apsolutna korist a niti apsolutna šteta tako da svaka dozvoljena stvar sadržava i štetu i obratno, ali Božija milost prema ljudima je htjela da se sigurni interesi i koristi ne zanemaruju zbog umišljene i rijetke štete.

Citirano pravilo: Uklanjanju štete se daje prednost nad pribavljanjem koristi, upotpunjuju druga potpravila od kojih su: Neznatna šteta se zanemaruju radi velike koristi, Oprašta se nenadna šteta radi stalne koristi i Ne zanemaruje se sigurna korist zbog umišljene štete. $\mathrm{Na}$ osnovu navedenog pravila izvedeni su i mnogi propisi od kojih su:

- Dozvoljeno je otvoriti stomak umrloj ženi radi vađenja novorođenčeta ukoliko se smatra da je živo, jer zaštita života je veći interes od štete narušavanja svetosti umrlog, jer se neznatna šteta podnosi radi velikog interesa. $^{22}$

${ }^{22}$ Ibn Nudžejm, El-Ešbahu ven-nazair, Darul-fikr, Damask, prvo izdanje, 1983., str. 97., Izuddin b. Abdusselam, Kavaidul-ahkam, 1/87. 
- Pijenje alkohola je zabranjeno i štetno, ali je dozvoljeno u prisili, jer je zaštita života i ekstremiteta preča od zaštite razuma na kraće vrijeme. U ovom slučaju je uništenje života i ekstremiteta trajna šteta, a opijanje i blokiranje razuma je privremena i uklanja se brzo otrježnjenjem.

- Kada bi neprijatelj od zarobljenih muslimana napravio živi zid da bi se zaštitio od muslimana i porazio ih, a u isto vrijeme zanemarivanje borbe protiv njih bi bila ogromna šteta i opasnost za muslimane, $u$ tom slučaju bi muslimanima bilo dozvoljeno da se bore protiv takvog neprijatelja pa makar u toj borbi pobili sve muslimane koji su u živom zidu i pored toga što su im životi sveti. Zbog njihova ubistva neće biti grješni, jer je nužda odbrane cijelog ummeta nalagala da se oni poubijaju zbog bojazni da se ne uništi islam i muslimani i da padnu pod vlast nevjernika. A pobijene muslimane će Allah posebno nagraditi. ${ }^{23}$

- Laž je također zabranjena šteta. Međutim, kada se putem nje može sigurno ukloniti veća šteta ili pribaviti veća korist od nje, onda ona postaje ponekad dozvoljena a ponekad obavezna - vadžib. Npr. kada je čovjeku potrebno da odobrovolji svoju ženu kako bi mogao s njom nastaviti živjeti lijep život, na putu realizacije tog cilja dozvoljava se laž, jer odvratnost laži koja ne šteti a niti koristi je neznatna u odnosu na tu štetu. Isto tako, ukoliko laž bude garantovala veći interes od njene odvratnosti dozvoljava se s ciljem postizanja tog interesa. Ista je stvar i sa laži radi pomirenja ljudi, jer je ona najpreča da bude dozvoljena zbog općeg interesa. Imam Izuddin u svom djelu je po ovom pravilu naveo mnogobrojne primjere. ${ }^{24}$

\section{Metoda selekcije interesa i šteta kad se među njima ne može naći kompromis}

Ponekad se može desiti da bude nemoguće preferirati jedan interes nad drugim zbog njihove identičnosti. U tom slučaju se primjenjuje metoda selekcije putem koje nekim se interesima daje predanost, dok se neki zanemaruju i potiskuju. Imam Izuddin b. Abdusselam je naveo mnoge primjere koji prikazuju ovu metodi od kojih su:

\footnotetext{
${ }^{23}$ Gazali, El-Mustesfa fi 'ilmil-usuli, Darul- kutubil -ilmijje, Bejrut, drugo izdanje, 1983., 1/294-295.

${ }^{24}$ Vidi: Izuddin b. Abduselam, Kavaidul-ahkam, 1/95.
} 
- Kada svjedok bude pozvan da u isto vrijeme svjedoči za dva identična slučaja, sam će odabrati na kojem će biti svjedok. Ukoliko ne budu identični i bude se bojao da će jedno od tih prava biti zanemareno ukoliko ne bude svjedočio a $\mathrm{u}$ isto vrijeme drugo pravo nema takav status, dužnost - vadžib mu je da svjedoči za prvi slučaj.

- Kada neko vidi da su u isto vrijeme napadnuta dva čovjeka čiji su životi jednako sveti i ne mogne ih obojicu odbraniti, odabrat će kojeg će braniti, ista je stvar i sa imovinom.

- Kada dođu dva siromaha da traže pomoć, odabrat će se kojem od njih će se dati sadaka ili će se ona podijeli među njima.

\section{Izvlačenje strelica kad su prava izjednačena}

Ova metoda se primjenjuje kada se izjednače prava ili interesi i ne bude ih moguće pomiriti ili preferirati, a niti primijeniti metodu selekcije. Ovoj metodi se pribjegava zbog uklanjanja mržnje i pakosti radi zadovoljstva s onim što sudbina dodijeli i Allah presudi. Izuddin b. Abdusselam i o ovoj metodi je naveo mnogobrojne primjere od kojih su:

- Izvlačenje kocke među suprugama prije putovanja da bi se na pravedan način izabrala ona koja će putovati.

- Kada dijelovi suvlasnika u nekretninama - zgrade ili zemljišta budu identični, u tom slučaju se ne smije primjeniti metoda selekcije, nego metod izvlačenja kocke zbog identičnosti prava i radi uklanjanja mržnje i zlobe.

- Kada se dva kandidata sa identičnim osobinama i sposobnostima jave na neku funkciju u tom slučaju će se odabir među njima izvesti putem izvlačenja kocke. Ista je stvar i sa učenjem ezana, prvim safom, pravom na njegu i odgajanje djeteta, kupanjem umrlog, starateljstvom nad djevojkom pri udaji kada su staratelju na istom stepenu srodstva, itd.

U tom smislu Izuddin Abdusselam je rekao: „Sva navedena prava imaju identične interese, ali je Zakonodavac propisao izvlačenje kocke kako bi neka od njih, na taj način, definirao i odredio radi uklanjanja prezira i netrpeljivosti koje mogu implicirati međusobnu mržnju, zavidnosti i inat. Onaj ko preuzme u ovom slučaju neki položaj tj. bez izvlačenja kocke bit će uzrok omraženosti i prezrenosti, te i zavidnosti od strane 
onoga koji nije izabran. Stoga je izvlačenje kocke propisano radi uklanjanja nereda i inata, a ne radi toga što je jedan od interesa preferiraniji u odnosu na drugi.، ${ }^{25}$

\section{Umjesto zaključka}

Studija je polučila sljedeće rezultate:

- cilj izrade ove studije je bio da se pojasne šerijatske metode i principi kojim se postiže pravilno i praktično balansiranje kontradiktornih interesa u slučaju kada ih je nemoguće pomiriti, ili između kontradiktornih šteta kada ih je nemoguće sve izbjeći, ili izmeđe kontradiktornih šteta i interesa $\mathrm{i}$ njihove primjenu $\mathrm{u}$ stvarnosti $\mathrm{i}$ realnosti.

- metodologija islamskog prava, po pitanju balansiranja interesa i šteta, počiva na četiri temeljne metode - pravila: metodi usklađivanja $\mathrm{i}$ pomirenja interesa koliko je to god moguće, metodi prevladavanja i preferiranja kod oprečnosti ako je pomirenje nemoguće, metodi selekcije kod identičnosti i nemogućnosti usklađivanja i pomirenja i metodi izvlačenja strelica između identičnih interesa i prava zbog uklanjanja zlobe i mržnje a radi zadovoljstva sa određenjem sudbinom.

- pravila fikha balansiranja u islamskom pravu nisu deklarativne nego praktične prirode, stoga cilj njihova izučavanja nije samo njihova puka teorijska spoznaja, nego prije svega praktična primjena.

- da bi se došlo do ispravnog i praktičnog balansiranja zaštićenog od svake vrste pretjerivanja neophodno je svakom onom koji se bavi tom vrstom islamskog prava uvažiti sljedeće principe:

a - poštovati šerijatsko značenje tekstova i to u okviru arapskog jezika i tradicije kao pomoćnog sredstva za razumijevanje i parametra za sve ideje i mišljenja.

b - poznavati povode objave kao mjerila za određena pojašnjenja za različite poglede i primjenu tekstova na stvarnost i realnost.

${ }^{25}$ Izuddin Abdusselam, Kavaidul-ahkam, 1/78. 
c - pridržavati se značenja izraza i formi koje su u svojim djelima definirali metodolozi islamskog prava, kao i logičkih pravila i zdrava razuma, te zdrave ljudske prirode.

d - ograničiti mišljenje i razmišljanje na opće intencije koje je šerijat definirao kao aksiome. Oni su potpuno jasni onima koji se bave šerijatskim pravom, jer šerijat je i objavljen radi realizacije ljudskih ovosvjetskih i onosvjetskih interesa stepenovanih po poznatim prioritetima: nužni, potrebni i poželjni.

e - koristiti naučna dostignuća i činjenice na svim segmentima života $\mathrm{i}$ njihovo konsultovanje pri proučavanju šerijatskih tekstova. $U$ isto vrijeme prihvatiti šerijatski tekst kao opću vrijednost i stimulans za istraživanje i razmišljanje, jer ljudska dostignuća i spoznaja ne mogu biti arbitri šerijatskom tekstu, nego samo od pomoći da se on razumije, $\mathrm{i} \mathrm{u}$ isto vrijeme on treba da ostane kao usmjerivačka vrijednost za definiranje naučnog cilja i intencije. ${ }^{26}$

f - razumjeti stvarnost putem izučavanja realnih okolnosti koje treba da budu precizno i sveobuhvatno shvaćene, te utemeljene na najispravnijim činjenicama i najpreciznijim podacima i statistikama. Ovdje posebno treba biti oprezan prema nestvarnim brojkama i statistikama koje se temelje na promidžbenim propagandama, nepotpunim podacima, nedovršenim istraživanjima i pitanjima koja su usmjerena da budu u službi parcijalnog cilja a ne generalne istine. ${ }^{27}$

- preporučuje se da se ovoj vrsti islamskog prava posveti veća pažnja i da se počne više zanimati za njega i proučavati zbog njegove neophodnosti u svakodnevnom životu a posebno kada je u pitanju tematika koja nije normirana pravnim tekstovima. U slučaju nepoznavanja ove vrste prava zatvaraju se mnoga vrata pravne fleksibilnosti i širine, i obratno gdje se omogućava komparaciju dva stanja, zatim preferiranje između dva pravna slučaja, potom balansiranje između dobiti i šteta kako na dugoročnom tako i na kratkoročnom planu, te na individualnom i kolektivnom nivou nakon

\footnotetext{
26 Gazali, Kejfe nete'amelu me'al-Kur'ani, El-M'ahedul-'alemijju lil-fikril-islami, drugo izdanje, 1992., str. 197.

${ }^{27}$ Karadavi, Evlevijatul- hareketil-islamijjeh, str. 30.
} 
čega se može odabrati ono što se smatra najbližim pribavljanju interesa ili njegovu upotpunjenju ili uklanjanju štete ili njenom smanjenju.

\section{Popis korištene literature:}

1. Bejheki, Es-Sunenul-kubra, Mektebetud-daril-Baz, Mekke, 1994.

2. Buhari, El-Džami'us-sahih, Dar Ibn Kesir i Jemame, Bejrut, 1987.

3. Buti, Davabitul-maslehati fiš-šeri'atil-islamijjeh, Muessesetur-risale, Bejrut, četvrto izdanje, 1983.

4. Buti, Fikhus-sire, Darul-fikr, Damask, 1996., 11. izdanje.

5. Ebu Davud, Sunen, Darul- fikr.

6. Gazali, Ihjau 'ulumid-din, Darul-m'arife, Bejrut.

7. Gazali, El-Mustesfa fi 'ilmil-usuli, Darul-kutubil - ilmijje, Bejrut, drugo izdanje, 1983.

8. Gazali, savremenik, Kejfe nete'amelu me'al-Kur'ani, El-M'ahedul'alemijju lil-fikril-islami, drugo izdanje, 1992.

9. Ibn Hišam, Es-Siretun-nebevijjeh, Darur-rejjan, Kairo, prvo izdanje, 1987. god.

10. Izuddin b. Abdusselam, Kava'idul-ahkami mesalihil-enam, Darulm'arife, Bejrut.

11. Karadavi, Evlevijatul-hareketil-islamijjeti fil-merhaletil-kadimeh, Muessesetur-risale, Bejrut, 13. izdanje, 1992.

12. Kurtubi, El-Džami'u li ahkamil-Kur'an, Darul-hadis, Kairo, prvo izdanje, 1994.

13. Nevevi, Šerhu Muslim, Ihjaut-turasil-arebi, Bejrut.

14. Ibn Nudžejm, El-Ešbahu ven-nazair, Darul-fikr, Damask, prvo izdanje, 1983.

15. Šatibi, El-Muvafekat fi usuliš-šeri'ah, Darul-m'arife, Bejrut, drugo izdanje 1996.

16. Zejle'i, Nasbur-rajeti li ehadisil-Hidaje, Darul-hadis, 1357. h. 
Sulejman Topoljak, $\mathrm{PhD}^{28}$

\section{BASICS OF UNDERSTANDING THE BALANCE OF BENEFITS AND HARM IN THE ISLAMIC LAW (FIQH AL-MUWAZANAT)}

\section{Abstract}

This study will attempt to clarify the methods of balancing between benefits and harm in the Islamic law. The legal balancing means science that aims to discover and explain the methods and ways through which we can compare between benefits and damages in the most beneficial scientific way, or between interest and damage when they come into collision and try to translate stated theorizing examples into reality. The most important principles or rules underlying Fiqh Al-Muwazanat, ie. legal balancing are:

1- balancing between the benefits in terms of their preferences and neglect,

2- balancing between harms in terms of their mandatory acceptance when they are impossible to avoid, and their neglect or delay,

3-balancing between benefits and harm in terms of defining the rules on which it is required to prefer the harm over the benefit, or to ignore the damage at the cost of benefits.

Regarding the legal balancing of benefits and harm, Islam follows the principle of harmonization and reconciliation between benefits whenever possible, and if not, then resorts to overcoming and preference. The subject of studying this type of Islamic law are Sharia regulations and standards, ie. acts of legal addresses which involve worldly and otherworldly interests because Sharia norms are related to these acts and interests. Sharia regulations and standards require just for the realization of human benefit and the removal of harm, as stated by Imam Suyuti who claims that all of God's commands and prohibitions ultimately aim to take into account the interests, and removal of harm is basically a kind of benefit.

Keywords: legal balancing, alignment, overcoming, benefits, damage, Fiqh, Islamic law.

${ }^{28}$ Faculty of Islamic Pedagogy in Bihac 


\section{الأستاذ الدكتور سليمان توبولياك'}

\section{أسس فقه الموازنات بين المصالح والمفاسد في الفقه الإسلامي}

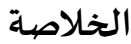

ستحاول هذه الدراسـة بيان مناهج الموازنة بين المصالح والمفاسـد في الفقه الإسلامي. يُقصَّد بفقه الموازنات العلم الذي يهدف إلى كشف وبيان المناهج والطرق التي عن طريقها بشكل أفضل وأكثر علمياة يتم موازنة بين المصالح بذاتها والمفاسد بذاتها أو بين المصالح والمفاسـد عندما تتعارض فيما بينها وتحويل الجانب النظري منه عن طريق الأمثلة إلى عالم الواقع. أهم الأسس أو المبادئ التي يقوم عليها فقاه الموازنات هي:

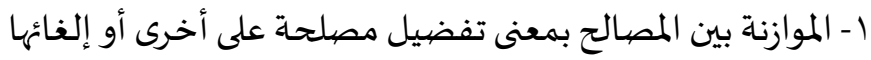

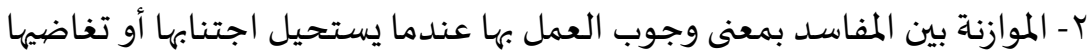

أو تأجيلها

ب- الموازنة بين المصالح والمفاسـد بمعنى تحديد القواعد التي تفضل فيها المفسدة على

$$
\text { المصلحة أو إلغاء المفاسد على حساب المصالح. }
$$

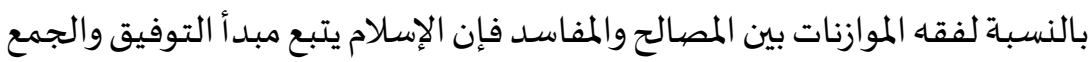

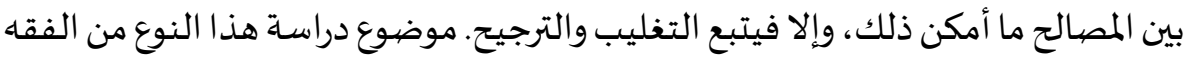
الإسلامي هو الأحكام، أي أعمال المكلفين التي تحتوي على مصالح المالف دنيوية وأخروية، لأن

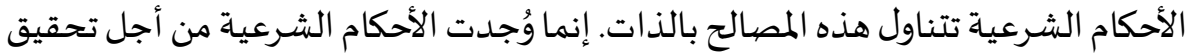

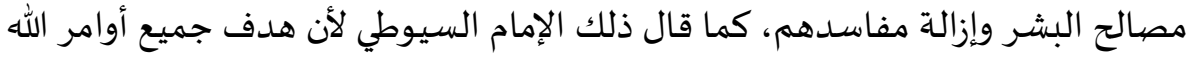

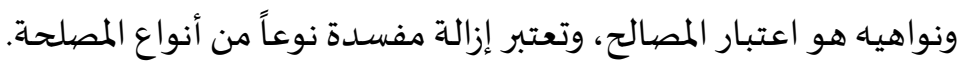

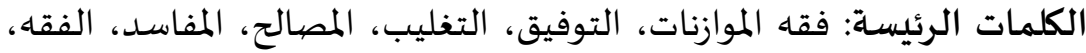

